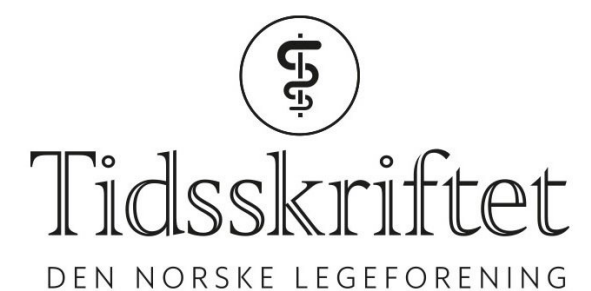

DEN NORSKE LEGEFORENING

\title{
Kortikosteroider til palliasjon hos kreftpasienter
}

DOKTORAVHANDLINGER

$\varnothing R N U L F$ PAULSEN

E-post:paor@sthf.no

Kortikosteroider ga ikke smertelindrende effekt, men bedring av fatigue og appetitt hos alvorlig syke kreftpasienter.

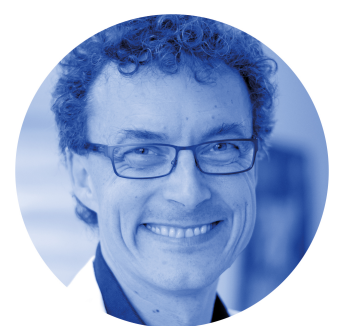

Foto: Sykehuset Telemark

Kreftpasienter opplever hyppig smerte, appetittløshet og trøtthet (fatigue).

Kortikosteroider blir ofte brukt for å lindre symptomer hos pasienter med langtkommet kreftsykdom, og smertelindring er en av indikasjonene.

I doktorgradsarbeidet mitt undersøkte jeg det vitenskapelige grunnlaget for denne praksisen. I en systematisk gjennomgang av publiserte studier fant vi at kortikosteroider kan ha en moderat smertelindrende effekt hos kreftpasienter, men kunnskapsgrunnlaget ble bedømt som svært svakt. Videre viste vi i en tverrsnittsstudie blant europeiske kreftpasienter at kortikosteroider ble hyppig brukt (av $50 \%$ av pasientene), mens paracetamol og ikke-steroide antiinflammatoriske midler (NSAID) ble begge brukt av $30 \%$.

I en placebokontrollert studie fant vi ingen smertelindrende effekt av metylprednisolon $32 \mathrm{mg}$ daglig i en uke hos alvorlig syke kreftpasienter som alle brukte sterke opioider. Vi fant imidleritid signifikant bedring av appetitt og reduksjon av fatigue etter behandling med kortikosteroider. Videre forskning må vise om behandlingen er effektiv ut over 1-2 uker. Videre gjorde vi en eksplorativ studie som indikerte at appetittløshet og fatigue var relatert til systemisk inflammasjon, henholdsvis IL-6 og CRP, og IL-1ra, hos disse pasientene.

Ettersom studien ikke påviste at kortikosteroider hadde smertelindrende effekt, indikerer funnene at vi ikke generelt bør anbefale disse medikamentene for lindring av kreftsmerte. Videre indikerer funnene at kortikosteroider gir bedre matlyst og mindre trøtthet hos alvorlig syke kreftpasienter. 


\section{Disputas}

$\emptyset$ rnulf Paulsen disputerte for ph.d.-graden ved Norges teknisk-naturvitenskapelige universitet 12. mai 2017. Tittelen på avhandlingen er Corticosteroids for Cancer Pain.

Publisert: 19. februar 2018. Tidsskr Nor Legeforen. DOI: 10.4045/tidsskr.17.1036

(C) Tidsskrift for Den norske legeforening 2020. Lastet ned fra tidsskriftet.no 